\title{
The Effects of Service Employees' Emotional Labor on Customer Loyalty in Wealth Management Service Organization
}

\author{
Yunxia Shi, Xinxin Bao*, Chunhao Ma, Wenpei Wei \\ School of Business Management, Shandong Technology and Business University, Yantai, China \\ Email: katiecloud@163.com, *165223510@qq.com
}

How to cite this paper: Shi, Y. X., Bao, X. X., Ma, C. H., \& Wei, W. P. (2020). The Effects of Service Employees' Emotional Labor on Customer Loyalty in Wealth Management Service Organization. Journal of Service Science and Management, 13, 498-515.

https://doi.org/10.4236/jssm.2020.133033

Received: May 7, 2020

Accepted: June 7, 2020

Published: June 10, 2020

Copyright $\odot 2020$ by author(s) and Scientific Research Publishing Inc. This work is licensed under the Creative Commons Attribution International License (CC BY 4.0).

http://creativecommons.org/licenses/by/4.0/ (c) (i) Open Access

\begin{abstract}
The wealth management firm meets greater competition in generating customer loyalty after China's 11 opening-up policy. According to emotional contagion and SOR theory, the effect of employees' competence on customer loyalty was firstly investigated. Secondly, the mediation effect of customers' trust was tested. Finally, the moderation effect of employees' emotional labor perceived by customers was investigated. After tested by Process Macro for SPSS, several results were obtained. Employees' competence positively predicts customer loyalty, and customers' trust plays a mediation effect. The deep acting (surface acting) strategy of employees plays a positive (negative) moderation effect in the relationship between employees' competence and customer trust. Theoretical and managerial implications related to emotional labor and trust were generated.
\end{abstract}

\section{Keywords}

Emotional Labor, Customer Loyalty, Trust, Competence, Wealth Management Service

\section{Introduction}

The office of the Financial Stability and Development Commission of the State Council of China issued 11 measures to open up the financial industry to the outside world in July, 2019 (China Economic Net, 2019). The "catfish effect" induced by foreign capital forces the regulation and transformation of domestic wealth management enterprises. Wealth management enterprises are typical service organization ( $\mathrm{Lu}$ et al., 2006) for its intensive interaction with customers. Service organizations are vulnerable to customer switching because of the high level of competition (Lam et al., 2004). A loyal customer is like an asset to an 
organization (Arora \& Narula, 2018). It can lead to customers' future repurchase and positive word of mouth. Customer loyalty promotes profitability (Hayes, 2008). Increased loyalty stimulates additional purchases, and loyal customers are less likely to switch brand preferences if competitors offer lower prices (Bowen \& Shoemaker, 1998). They can help to keep a dominant position in competition and gain more profit (Geng \& Jia, 2014). The cost of acquiring new customers is 4 - 5 times of retaining current ones (Desatnick \& Detzel, 1988). How to preserve customer and enhance customer loyalty has been an issue for the practitioners. Consumers value the frontline employees' service because of the interaction and trustworthiness that they offer (Riquelme et al., 2016; Larivière et al., 2017; Lee, 2017). Frontline employees appear to be the essential element capable of assuring a firm's success (Cadwallader et al., 2010).

Frontline employees' competences are especially important in creating a pleasurable and convenient service encounter (Lucia-Palacios et al., 2020). Nguyen confirmed that the competence of Canadian financial service employees is the antecedent of customer loyalty (Nguyen, 2016). Wealth management is still in its infancy in China, and the study on the influence factors of customer loyalty is rare. Whether Nguyen's study result is applicable in China needs to be tested.

Nguyen suggested that employees' competence directly affect customer loyalty, whereas Suhail et al. suggested that customer trust has a positive influence on customer loyalty in an Indian retail banking sector (Bhat et al., 2018). This indicates that both competence and trust are antecedents of customer loyalty. However, in the context of wealth management, the correlation among employee competence, trust, and customer loyalty has yet to be examined. In the current study, we argue that there is a process before customers become loyal to an enterprise, and employees' competence needs a mediation mechanism (i.e. trust) to influence customer loyalty instead of directly. Mayer (2008) and Guiso et al. $(2004,2008)$ show that Financial transactions are very trust-intensive and that trust in financial markets is an important factor for financial development. As the main business is to manage customers' money, it is important to achieve customers' trust for wealth management organization. Without customers' trust, only high competence is not enough to achieve customer loyalty.

Creating loyalty for corporate brands has become more challenging due to minimal differentiation among their competitive offerings and similar corporate and organizational values among competitors (Anisimova, 2007; Dawes, Meyer-Waarden, \& Driesener, 2015). In this sense, building and maintaining effective relationships with consumers is crucial for gaining customer loyalty (Gbadamosi, 2015). This relationship refers to the emotional component between consumer and firm. Employees' emotion regulation during service interactions affects customer loyalty, all of which are critical for service success (SegerGuttmann \& Medler-Liraz, 2016). Employees are required to regulate emotion expression strategically when interacting with customers, that is, to show positive emotion and suppress negative emotion through facial expression or cognition regulation. This indicates employees have exposed to emotional labor. Ac- 
cording to emotional contagion theory, employees' positive emotion will be experienced by customers. At the same time, customers will have more trust with employees if they show more professional competence. Otherwise, customers will doubt employees' competence if they experience their faked emotion display. Previous study has investigated emotional labor's moderation effect on the relationship between customer participation and buying (Seger-Guttmann \& Medler-Liraz, 2016). However, there is a very limited understanding about the moderation effect of emotional labor in the wealth management context. The current study aims to investigate the mechanism of customer loyalty in the wealth management organization from the perspective of emotional labor.

\section{Literature Review and Hypothesis}

\subsection{Customer Loyalty}

Customer loyalty is an important factor in enhancing the sustainability of a company through maintaining existing customers and strengthening relationships (Hallowell, 1996). Customer loyalty includes two dimensions: attitudinal and behavioral (Chandrashekaran et al., 2007). From the attitudinal perspective, customer loyalty can be interpreted as a degree of positive attitude or preference towards a product or service (Jacoby \& Chesnut, 1978). It can be described as the intention to recommend and repurchase (Kumar et al., 2013). Attitudinal loyalty expresses a consumer's desire to establish a relationship with an enterprise. The problem is to verify if this intention will transfer to an action (Nguyen, 2016). From the behavioral perspective, customer loyalty is described as the repeat purchasing or use of a given service or product over time (Leenheer et al., 2007). Behavioral loyalty includes retention, repurchase, duration of the relationship (Kumar et al., 2013). Whether perceived as an attitude or type of behavior, loyalty is one of many elements that influence consumers' buying decisions (Nguyen, 2016).

\subsection{Competence}

The competence of service employees is a body of knowledge gained from training and experience. It constitutes their capacity to provide transactions requested by the customer and to perform in a way to meet his or her expectations (Barclay \& Smith, 1997). This competence usually relies on the ability of service employees to acquire and apply this knowledge in accomplishing their job. It is to ensure the success of transactions during the service encounter and help to increase customer's trust towards the firm (Xie \& Peng, 2009) and customer retention (Delcourt et al., 2013).

Competence has two components: technical expertise and problem-solving skills (Sirdeshmukh et al., 2002). Technical expertise is considered as a cognitive component of competence. It is the degree of knowledge directly related to the firm's activity. This expertise is requested as a necessary qualification in the recruitment process. It is possessed individually through the employee's professional training. Technical expertise can be accumulated on the job and enhanced 
by continuing education. Due to its significant impact on the outcome of transactions, technical expertise can help service employees to meet the consumer's expectations and to gain his or her trust towards the firm. The problem-solving skill is the behavioral component of competence. It represents the ability of service employees to tackle conflictual issues, i.e., service failure. In service recovery, employees have to take into consideration the motivations of both parties while attempting to satisfy the customer's needs and protecting the firm's interests. The problem-solving skill of service employees is the result of their individual personality traits and their perceptions of the social interaction with customers during the service encounter (Hartline et al., 2003; Solomon et al., 1985). The two components of competence are the same important components in attracting customers.

Previous research has examined the influences of employee competence on various aspects of the firm, including corporate image (Nguyen \& Leclerc, 2011), service quality, customer satisfaction (Arora \& Narula, 2018) and customer loyalty (Nguyen, 2016). In the context of wealth management service, the competence of employees is specifically geared towards the success of the transaction that meets the customer's requirements and in turn the loyalty to the firm. Hence the first hypothesis can be stated as follows:

H1: Wealth management service employees' competence is positively related to customer loyalty.

\subsection{Trust}

Trust is the expectation held by a consumer that the service provider is dependable and can be relied high on to deliver on its promises and to put the client's interest first. It is an essential ingredient for stable relationships (Kimes, 2010). Trust removes the vulnerability to exploitation (Hansen, 2012). Consumers' perceived trust in a relationship partner has been found to influence overall satisfaction and generate behaviors that increase cooperation, loyalty (Tran \& Strutton, 2020) and performance (Kinnel, 2010). The development of trust between the consumer and the financial service provider may promote relational exchanges that prove to add value for both partners (Winchester \& Huston, 2017). As trust decisions involve both thinking (cognitive) and feeling (affective) process (Srivastava et al., 2015), the current study examines the concept of trust through its cognitive and affective components. Cognitive trust is driven by knowledge and a rational thought process (Wang et al., 2016), whereas affective trust is driven by feelings and emotional exchanges (Albert \& Merunka, 2013; Dowell et al., 2015).

Cognitive trust is an instrumental inference made from information about another's behavior under specific circumstances (Zhang, 2015). The level of cognitive trust may reflect integrity factors including honesty and fairness of the referent (Dirks \& Ferrin, 2002). Affective trust relates to the extent to which one feels secure and comfortable about the trustee (Komiak \& Benbasat, 2006; Zhang, 2015). 


\subsection{Stimulus-Organism-Response Theory}

Stimulus-Organism-Response (SOR) theory was developed by environmental psychologists. The theory posits the environment functions as a stimulus. Organisms' external environments influence their internal reactions. These reactions, in turn, promote external behavioral responses among organisms (Mehrabian \& Russell, 1974). These internal organism responses include affective (emotional) and cognitive elements. These emotional and cognitive beliefs mediate approach or avoidance responses toward the environment (Tran \& Strutton, 2020). According to SOR theory, employees' competence might function as an environmental stimulus; trust (i.e., customers' internal reaction) as an organism; and customer loyalty functioned as behavioral responses. Hence, we hypothesize as follows:

H2: Trust mediates the relationship between employees' competence and customer loyalty.

\subsection{Emotional Labor}

In the workplace, employees should not only pay mental and physical labor, but also emotional labor. In 1983, American sociologist Hochschild proposed the concept of emotional labor on the basis of absorbing Goffman's Parody theory through the analysis of Delta Air flight attendants (Hochschild, 1983). He defined it as "to get paid, front-line employees manage their own emotions, and perform to customers according to the organization's requirements through facial expression or body language". Later studies found that emotional labor in the workplace also exists in other situations, such as doctor-patient relationship, colleague relationship (Geddes \& Lindebaum, 2020), collective decision making, negotiation and subordinate relationship of leadership (Van Kleef et al., 2012). This paper focuses on the customer service situation. The core of emotional labor is an effort to regulate emotions. This regulation process includes two strategies: deep acting and surface acting. Deep acting is a kind of antecedent-focused emotion regulation strategy (Gross, 1998). It needs to reappraise the situation to regulate the inner feelings, and then express the positive emotions required by the organization (through facial expression, tone, gesture and body posture). Surface acting is reaction-focused, which only needs to regulate the expression of emotions, that is, to suppress negative emotions and show positive ones, although the real feelings of the heart remain the same (Grandey, 2000). Emotions have internal effects, that is, employees engaged in emotional labor will have an impact on themselves, such as loss of self (Hochschild, 1983), emotional exhaustion (Grandey \& Melloy, 2017), burnout, health problems (Zapf, 2002), and low job satisfaction. Emotions also have interpersonal effects, that is, employees engaged in emotional labor will have an impact on customers' emotion, attitude, cognition and behavior (Van Kleef, 2016).

Grandey and Melloy's research suggested that employees' deep acting strategy is related to customer positive outcomes, while surface acting is the opposite 
(Grandey \& Melloy, 2017). Taeshik et al. found that the two strategies of hotel employees' emotional labor affect customer loyalty through customers' positive emotions and perceived service quality. These researches mainly focus on hotel and other service industries. Grandey suggested that emotional labor research needs to be combined with certain social and cultural situations (Grandey \& Melloy, 2017). The situation of wealth management has its unique characteristics. It makes financial planning for customers by taking customers as the center. According to the theory of emotional contagion, customers will perceive employees' emotions and be infected. Therefore, the positive emotional display of employees is conducive to the good emotional experience of customers. On the contrary, customers will doubt the service ability of employees if they perceive the fake emotional display of employees. This study supposes that emotional labor moderates the positive effect of employee competence on customer trust. That is to say, the stronger the employees' professional knowledge and problem-solving ability, the more trust the customers will have, and the sincere service (deep acting) of the employees will strengthen this relationship; on the contrary, the false display (surface acting) will weaken this relationship.

Customer perceived and employee perceived emotional labor are two different concepts (Gong et al., 2020). In the process of establishing the boundary of host and guest emotional communication, customers play a leading role (Christou et al., 2019). Therefore, the current study chooses the employees' emotional labor perceived by customers to study its moderating effect on the positive relationship between employee competence and customer trust. As customers perceive emotional labor in two ways at the same time, deep acting and surface acting are regarded as two independent constructs to explain emotional labor. Accordingly, we hypothesize as follows:

H3a: Employees' deep acting strategy positively moderates the relationship between employees' competence and customer trust;

H3b: Employees' surface acting strategy negatively moderates the relationship between employees' competence and customer trust.

To sum up, the conceptual model is shown in Figure 1.

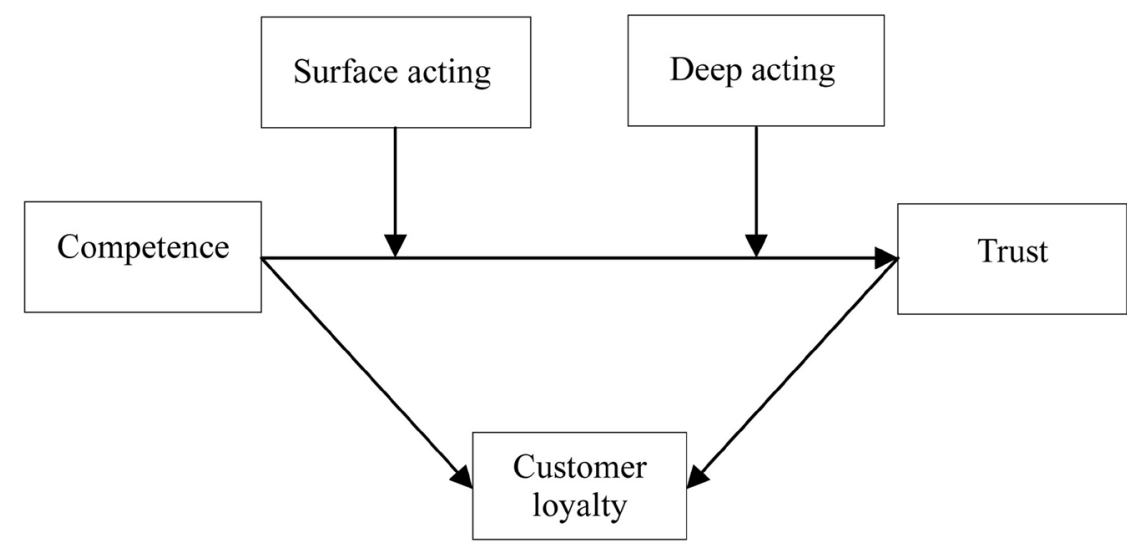

Figure 1. The conceptual model. 


\section{Methodology}

\subsection{Data Collection}

Data was gathered using an online survey. To test the tool, a pilot test was first carried out from January 14 to 23, 2020 through WeChat. This initial study sought to improve the questions and remove unclear and/or ambiguous items in order to refine the survey content and structure. Preliminary evidence presented reliable and valid scales. Following the pre-test, the formal research data was collected on Mar. 2020 through social media platforms. After removing 21 incomplete and invalid (income below 4000) questionnaires, we finally get 183 (>150) (Rigdon, 2005) valid responses. Table 1 lists the basic information of the sample. More than $50 \%$ of respondents were men; more than $60 \%$ of them were older than 36 years of age, and more than $90 \%$ of the income were above 5000 .

We used Harman's single-factor test to assess common method bias. The first factor explains $35.3 \%$ of the covariance amongst all constructs. This is less than $50 \%$, which means that common method bias does not affect our data (Podsakoff et al., 2003, 2012). This study entails all the common shortcomings involved in using an open access sampling methodology (e.g., self-selection bias, lack of information about non-respondents, and unknown response rate) (Kuss et al., 2014).

\subsection{Scale Design}

The questionnaire items were based on those reported in the literature and adapted for this context. Five items were used for the measurement of competence according to Nguyen's study (Nguyen, 2016). Two items were for the technical expertise component and three other items are for the problem-solving skills component. Trust included ten items according to Sena et al.'s work (Ozdemir et al., 2020), is drawn from studies by Johnson \& Grayson (2005), McAllister (1995), Massey \& Dawes (2007), Massey \& Kyriazis (2007) and Wang \& Qiu et al. (2016). Six items were used to measure customer loyalty according to Nguyen's study which was based on the work of Zeithaml et al. (1996). We measured surface acting using Groth's et al. (2009) three-item scale and deep acting using Brotheridge \& Lee's (2003) three-item scale. All items for each question were measured with Likert's 5-point range scale, from "strongly disagree" (1) to "strongly agree" (5) (see Appendix).

Table 1. Respondents' socio-demographic characteristics.

\begin{tabular}{cccccccc}
\hline Variable & Group & Frequency & $(\%)$ & Variable & Group & Frequency & $(\%)$ \\
\hline Gender & Female & 85 & 46.4 & Age & $20-25$ & 32 & 17.5 \\
& Male & 98 & 53.6 & & $26-35$ & 37 & 20.2 \\
Income & $4000-5000$ & 16 & 8.7 & & $36-45$ & 49 & 26.8 \\
(RMB) & $5000-10,000$ & 69 & 37.7 & & $46-55$ & 39 & 21.3 \\
& Above 10,000 & 98 & 53.6 & & Above 55 & 26 & 14.2 \\
\hline
\end{tabular}


Our control variables included gender and income. Mittal et al. (2019) investigated that female are more satisfied and loyal to their bank compared to male. Including income as a control variable enabled us to control the effect of investing power on consumer loyalty.

\section{Data Analyses and Results}

\subsection{Indicator Reliability and Validity}

The linkage between constructs was tested and analyzed using SPSS 21.0 and AMOS software. Structural equation modelling (SEM), namely partial least squares (PLS) path modelling was employed. All of the constructs were measured by reflective constructs. As shown in Table 2, the Cronbach's alphas for competence,

Table 2. Indicators' reliability and validity.

\begin{tabular}{|c|c|c|c|c|c|}
\hline Variable & Item & Factor loading & $\alpha$ & AVE & $\mathrm{CR}$ \\
\hline \multirow[t]{3}{*}{ SA } & sal & 0.779 & 0.648 & 0.588 & 0.81 \\
\hline & sa2 & 0.749 & & & \\
\hline & sa3 & 0.772 & & & \\
\hline \multirow[t]{3}{*}{ DA } & da 1 & 0.813 & 0.76 & 0.677 & 0.863 \\
\hline & da2 & 0.823 & & & \\
\hline & da3 & 0.832 & & & \\
\hline EL & & & 0.572 & 0.632 & 0.912 \\
\hline \multirow[t]{10}{*}{$\mathrm{TR}$} & $\operatorname{tr} 1$ & 0.799 & 0.829 & 0.601 & 0.85 \\
\hline & $\operatorname{tr} 2$ & 0.813 & & & \\
\hline & $\operatorname{tr} 3$ & 0.822 & & & \\
\hline & $\operatorname{tr} 4$ & 0.818 & & & \\
\hline & $\operatorname{tr} 5$ & 0.844 & & & \\
\hline & $\operatorname{tr} 6$ & 0.805 & & & \\
\hline & $\operatorname{tr} 7$ & 0.91 & & & \\
\hline & $\operatorname{tr} 8$ & 0.833 & & & \\
\hline & $\operatorname{tr} 9$ & 0.816 & & & \\
\hline & $\operatorname{tr} 10$ & 0.787 & & & \\
\hline \multirow[t]{5}{*}{$\mathrm{CO}$} & col & 0.826 & 0.801 & 0.576 & 0.872 \\
\hline & $\mathrm{co} 2$ & 0.788 & & & \\
\hline & $\operatorname{co} 3$ & 0.769 & & & \\
\hline & $\operatorname{co} 4$ & 0.801 & & & \\
\hline & $\operatorname{co} 5$ & 0.869 & & & \\
\hline \multirow[t]{6}{*}{$\mathrm{CL}$} & $\mathrm{cll}$ & 0.92 & 0.919 & 0.95 & 0.934 \\
\hline & $\mathrm{cl} 2$ & 0.911 & & & \\
\hline & $\mathrm{cl} 3$ & 0.854 & & & \\
\hline & $\mathrm{cl} 4$ & 0.899 & & & \\
\hline & $\mathrm{cl} 5$ & 0.871 & & & \\
\hline & $\mathrm{cl} 6$ & 0.88 & & & \\
\hline
\end{tabular}

Note: SA-surface acting; DA-deep acting; EL-emotional labor; TR-trust; CO-competence; CL-customer loyalty. 
trust, customer loyalty, surface acting and deep acting were 0.801, 0.829, 0.919, 0.648 and 0.76 respectively, greater than 0.6 . In order to test convergent validity, we analyzed factor loading and average variance extracted (AVE). All of the factor loadings were greater than 0.5 . Fornell \& Larcker (1981) suggested that the AVE should present a value not lower than 0.5 , which reflects adequate convergent validity (Götz et al., 2010). Consequently, and according to the results shown in Table 2, all constructs indicate AVE greater than 0.5.

To investigate the discriminant validity of the variables, we conducted confirmatory factor analysis (CFA) using AMOS and examined the fit indices of the hypothesized 3-factor model (i.e., competence, trust and customer loyalty). The CFA results (Table 3) show that the hypothesized 3-factor model fit the data well $\left(\chi^{2} / \mathrm{df}=1.10, \mathrm{NFI}=0.92, \mathrm{RFI}=0.94\right.$, TLI $=1.00, \mathrm{IFI}=1.00, \mathrm{RMSEA}=$ 0.003). As shown in Table 4, most values of the correlation coefficients between the independent variables were below the cut-off value of 0.7 (Field, 2009; Pallant, 2007). The composite reliability (CR) of each construct ranged from 0.81 to 0.98; the square root of AVE of each construct was greater than its correlations with other constructs (Table 4) which indicates good discriminant validity of the scales.

\subsection{Structural Model and Hypotheses Testing}

Through Pearson's correlation analysis, we evaluated the correlation of the constructs, as shown in Table 4. We can conclude from Table 4 that employee competence was positively related with costomer trust and loyalty $(\beta=0.424$, $0.503, p<0.01)$; surface acting was negatively related with customer trust $(\beta=$ $-0.338, p<0.05)$; deep acting was positively related with customer trust $(\beta=$ $0.609, p<0.01)$. The amounts of the sample were greater than 100 , we used maximum likelihood estimation method (MLE) to evaluate the structure model (Hou et al., 2004). The results of the path analysis is shown in Figure $2\left(\chi^{2}=\right.$

Table 3. Confirmatory factor analysis.

\begin{tabular}{ccccccc}
\hline Fit index & $\chi^{2} / \mathrm{df}$ & RMSEA & NFI & RFI & IFI & TLI \\
\hline Standard & $(<3.000)$ & $(<0.080)$ & $(>0.900)$ & $(>0.900)$ & $(>0.900)$ & $(>0.900)$ \\
Value & 1.10 & 0.003 & 0.92 & 0.939 & 1.000 & 1.000 \\
\hline
\end{tabular}

Table 4. Correlations among variables.

\begin{tabular}{cccccc}
\hline & $\mathrm{CO}$ & $\mathrm{TR}$ & $\mathrm{CL}$ & $\mathrm{SA}$ & $\mathrm{DA}$ \\
\hline $\mathrm{CO}$ & $\mathbf{0 . 6 9}$ & & & & \\
$\mathrm{TR}$ & $0.424^{* *}$ & $\mathbf{0 . 6 3 3}$ & & & \\
$\mathrm{CL}$ & $0.503^{* *}$ & $0.608^{* *}$ & $\mathbf{0 . 5 9 9}$ & & \\
$\mathrm{SA}$ & -0.045 & $-0.338^{*}$ & $-0.466^{*}$ & $\mathbf{0 . 4 0 1}$ & \\
$\mathrm{DA}$ & $0.538^{*}$ & $0.609^{* *}$ & $0.558^{* *}$ & $-0.257^{\star *}$ & $\mathbf{0 . 3 2 5}$ \\
\hline
\end{tabular}

Note: ${ }^{\star} p<0.05 ;{ }^{* *} p<0.01$ (two-tailed). Boldface letter is the square root of AVE. DA-deep acting; SA-surface acting; CO—competence; TR—trust; CL—customer loyalty. 
11.87, $\left.\mathrm{df}=18, \chi^{2} / \mathrm{df}=0.659, \mathrm{CFI}=1.000, \mathrm{PNFI}=0.476, \mathrm{RMSEA}=0.000\right)$. Competence is positively related to customer loyalty, supported $\mathrm{H} 1$.

\subsection{Mediation and the Moderated Mediation Effect}

To test the mediation and moderated mediation hypotheses, we used the PROCESS macro for SPSS (version 3.0) (Hayes, 2018). In Table 5 and Table 6, we provided estimates of the mediation and moderated mediation effects, along with $95 \%$ bias-corrected bootstrapped confidence intervals of our path estimates. As suggested in $\mathrm{H} 2$, customer trust mediates the positive relationship between employees' competence and customer loyalty (95\% CI $[0.15,0.26])$. H2 was supported.

$\mathrm{H} 3 \mathrm{a}$ states that the mediating effect of customer trust on the relationship between employees' competence and customer loyalty is positively moderated by employees' deep acting. The index of moderated mediation indicated that CI did not include zero (95\% CI $[0.11,0.29])$. So H3a was supported. A 95\% bootstrap confidence interval includes zero only when customer trust is relatively low $(-1 \mathrm{SD})(95 \% \mathrm{CI}[-0.01,0.33])$. H3b states that the mediating effect of customer

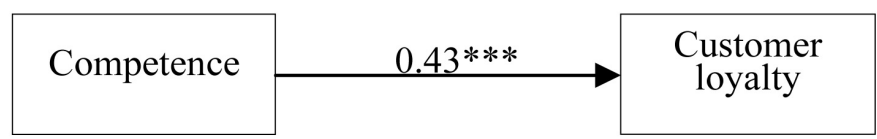

Figure 2. Results of the structure model testing.

Table 5. Mediation effect of trust.

\begin{tabular}{ccc}
\hline Path & Effect & 95\% bias-corrected bootstrap confidence interval \\
\hline $\mathrm{CO} \rightarrow \mathrm{TR} \rightarrow \mathrm{CL}$ & 0.27 & $0.15,0.26$ \\
\hline
\end{tabular}

CO-competence; TR—trust; CL—customer loyalty.

Table 6. Moderated mediation effects model predicting customer loyalty.

\begin{tabular}{cccc}
\hline & Path & Effect & $\begin{array}{c}\text { 95\% bias-corrected bootstrap } \\
\text { confidence interval }\end{array}$ \\
\hline DA & CO $\rightarrow$ TR $\rightarrow$ CL & & \\
-1 SD & 0.21 & $-0.01,0.33$ \\
Mean & 0.28 & $0.19,0.39$ \\
+1 SD & 0.32 & $0.26,0.48$ \\
Index of moderated mediation & & 0.15 & $0.11,0.29$ \\
SA & CO $\rightarrow$ TR $\rightarrow$ CL & & $-0.05,0.19$ \\
-1 SD & & -0.06 & $-0.17,-0.04$ \\
Mean & & -0.09 & $-0.25,-0.11$ \\
+1 SD & & -0.17 & $-0.12,-0.02$
\end{tabular}

DA—deep acting; SA—surface acting; $\mathrm{CO}$ —competence; TR—trust; CL—customer loyalty. 
trust on the relationship between employees' competence and customer loyalty is positively moderated by employees' surface acting. The index of moderated mediation indicated that CI did not include zero (95\% CI $[-0.12,-0.02])$. A 95\% bootstrap confidence interval includes zero only when customer trust is relatively low (-1 SD) (95\% CI $[-0.05,0.19])$. So H3b was supported.

\section{Discussion}

The frontline employees play a vital role in wealth management organization. According to the emotional contagion theory and SOR theory, the conceptual framework of the relationship among employees' competence, customer trust and loyalty was supposed and tested. Several results have reached.

Firstly, employees' competence (including professional knowledge and problem-solving ability) positively influences customer loyalty. This indicates that wealth management service organization should primarily strengthen employees' competence through training and other education. Specific hiring strategy should be employed to select suitable employees.

Secondly, trust plays mediation role in the positive relationship between employees' competence and customer loyalty. Besides competence, wealth management service organization should seek for other practical trust building techniques.

Thirdly, employees' deep acting display strategy positively moderate the positive relationship between employees' competence and customer loyalty, while surface acting plays a negative role. In experience economy era, customers' experiences could be affected by the nature of service employees' emotional labor, which can act as a potentially damaging outside source (Groth et al., 2009). Wealth management service organization should encourage employees to display genuine emotions (deep acting). Unique HRM policy should be employed, such as recruitment, selection, performance evaluation, etc.

\subsection{Theoretical and Managerial Implications}

From a theoretical perspective, the current study has contributed to understanding the mediation and moderation factors impacting customer loyalty. Allied to this, emotional contagion theory and SOR theory have played a critical role in this study. Its major innovation and theoretical contribution is in introducing emotional labor's moderation effect into wealth management context. To the best of our knowledge, this is one of the rare empirical research that investigates emotional labor's moderation effect on customer loyalty in wealth management service organization. The result shows that employees' emotional labor as well as are simultaneously important to generate customer loyalty.

From a practical perspective, there are important implications for wealth management practitioners and universities. University is the place that fosters future practitoners. The courses offered should take emotional labor education into consideration. Nowadays, emotional labor is highlighted in most service 
organizations especially financial corporates. These corporates pay to train employees necessary emotion expression. For the cost reduction purpose, we advise universities to add emotional labor course in the wealth management-related majors. Through this, the overall cost our society will decrease. This will increase university's popularity in society and the employment rate will be raised.

Practitioners sought to raise customer loyalty because it is less costly and more beneficial. This study suggests employees' competence is the primary element to influence customer loyalty. In practice, we should ensure employees' professional knowledge and problem-solving ability firstly. This could be realized by entrance training and timely evaluation. The mediation effect of turst indicates that obtaining customers' trust is also important in fostering loyal customers. Wealth management service organization should put more efforts in earning trust. Sharpe et al. (2007) investigated communication strategies which lead to trust. He found that being comfortable (or calm) with client expressions of strong emotions; actively seeking to understand clients' personalities, family history, and values; and involving the consumer in a systematic process for identifying their values and goals are all practical techniques for building consumer trust.

\subsection{Limitations and Future Research}

This research has some limitations unavoidably. First, the study is subject to all of the shortcomings that exist regarding open access sampling (e.g., self-selection bias, lack of information about non-respondents, unknown response rate) (Kuss et al., 2014). However, the full range of scores on all variables was represented in the data, which normally strengthens the validity of estimated relationships between constructs. Second, the sample size is 183, its representativeness may be not enough. Future research can broaden the sample size to enhance the representativeness. Thirdly, we only tested one antecedent (competence), one mediation factor (trust) and one moderation factor (emotional labor) of customer loyalty, other antecedents, mediation and moderation factors should be included in order to obtain a comprehensive understanding of customer loyalty in future.

\section{Funding}

Supported by Wealth Management Project of Shandong Technology and Business University (No: 2019ZBKY042).

\section{Conflicts of Interest}

The authors declare no conflicts of interest regarding the publication of this paper.

\section{References}

Albert, N., \& Merunka, D. (2013). The Role of Brand Love in Consumer-Brand Relationships. Journal of Consumer Marketing, 30, 258-266.

https://doi.org/10.1108/07363761311328928 
Anisimova, T. A. (2007). The Effects of Corporate Brand Attributes on Attitudinal and Behavioural Consumer Loyalty. Journal of Consumer Marketing, 24, 395-405. https://doi.org/10.1108/07363760710834816

Arora, P., \& Narula, S. (2018). Linkages between Service Quality, Customer Satisfaction and Customer Loyalty: A Literature Review. The IUP Journal of Marketing Management, 17, 30-54. https://doi.org/10.5220/0008436300140019

Barclay, D. W., \& Smith, J. B. (1997). The Effects of Organizational Differences and Trust on the Effectiveness of Selling Partner Relationships. Journal of Marketing, 61, 3-21. https://doi.org/10.1177/002224299706100102

Bhat, S. A., Darzi, M. A., \& Parrey, S. H. (2018). Antecedents of Customer Loyalty in Banking Sector: A Mediational Study. Vikalpa, 43, 92-105. https://doi.org/10.1177/0256090918774697

Bowen, J. T., \& Shoemaker, S. (1998). Loyalty: A Strategic Commitment. Cornell Hotel \& Restaurant Administration Quarterly, 39, 12-25. https://doi.org/10.1177/001088049803900104

Brotheridge, C. M., \& Lee, R. T. (2003). Development and Validation of the Emotional Labor Scale. Journal of Occupational and Organizational Psychology, 76, 365-379. https://doi.org/10.1348/096317903769647229

Cadwallader, S., Jarvis, C. B., Bitner, M. J., \& Ostrom, A. L. (2010). Frontline Employee Motivation to Participate in Service Innovation Implementation. Journal of the Academy of Marketing Science, 38, 219-239. https://doi.org/10.1007/s11747-009-0151-3

Chandrashekaran, M., Rotte, K., Tax, S., \& Grewal, R. (2007). Satisfaction Strength and Customer Loyalty. Journal of Marketing Research, 44, 153-163. https://doi.org/10.1509/jmkr.44.1.153

China Economic Net (2019). Financial Commission of the State Council Issued 11 Measures to Open Up the Financial Industry to the outside World. http://www.ce.cn/xwzx/gnsz/gdxw/201907/20/t20190720_32676444.shtml

Christou, P., Avloniti, A., \& Farmaki, A. (2019). Guests' Perceptions of Emotionally Expressive and Non-Expressive Service Providers within the Hospitality Context. International Journal of Hospitality Management, 76, 152-162. https://doi.org/10.1016/j.ijhm.2018.05.005

Dawes, J., Meyer-Waarden, L., \& Driesener, C. (2015). Has Brand Loyalty Declined? A Longitudinal Analysis of Repeat Purchase Behavior in the UK and US. Journal of Business Research, 68, 425-432. https://doi.org/10.1016/j.jbusres.2014.06.006

Delcourt, C., Gremler, D. D., van Riel, A. C. R., \& van Birgelen, M. (2013). Effects of Perceived Employee Emotional Competence on Customer Satisfaction and Loyalty. The Mediating Role of Rapport. Journal of Service Management, 24, 5-24. https://doi.org/10.1108/09564231311304161

Desatnick, R. L., \& Detzel, D. (1988). Managing to Keep the Customer. Boston, MA: Houghton Mifflin.

Dirks, K. T., \& Ferrin, D. L. (2002). Trust in Leadership: Meta-Analytic Findings and Implications for Research and Practice. Journal of Applied Psychology, 87, 611-628. https://doi.org/10.1037/0021-9010.87.4.611

Dowell, D., Morrison, M., \& Heffernan, T. (2015). The Changing Importance of Affective Trust and Cognitive Trust across the Relationship Lifecycle: A Study of Business-to-Business Relationships. Industrial Marketing Management, 44, 119-130. https://doi.org/10.1016/j.indmarman.2014.10.016

Field, A. (2009). Discovering Statistics Using SPSS (3rd ed.). London: SAGE Publications. 
Fornell, C., \& Larcker, D. F. (1981). Evaluating Structural Equation Models with Unobservable Variables and Measurement Error. Journal of Marketing Research, 18, 39-50. https://doi.org/10.1177/002224378101800104

Gbadamosi, A. (2015). Brand Personification and Symbolic Consumption among Ethnic Minority Teenage Consumers: An Empirical Study. Journal of Brand Management, 22, 737-754. https://doi.org/10.1057/bm.2015.40

Geddes, D., \& Lindebaum, D. (2020). Unpacking the "Why" behind Strategic Emotion Expression at Work: A Narrative Review and Proposed Taxonomy. European Management Journal.

Geng, L. H., \& Jia, J. M. (2014). An Analysis of the Influence Mechanism of Consumer Sentiment on Brand Loyalty in Different Consumer Experiences. Journal of Marketing Science, 10, 35-51.

Gong, T., Park, J. K., \& Hyun, H. (2020). Customer Response toward Employees' Emotional Labor in Service Industry Settings. Journal of Retailing and Consumer Services, 52, Article ID: 101899. https://doi.org/10.1016/j.jretconser.2019.101899

Götz, O., Liehr-Gobbers, K., \& Krafft, M. (2010). Evaluation of Structural Equation Models Using the Partial Least Squares (PLS) Approach. In Handbook of Partial Least Squares (pp. 691-711). Berlin: Springer. https://doi.org/10.1007/978-3-540-32827-8_30

Grandey, A. A. (2000). Emotion Regulation in the Workplace: A New Way to Conceptualize Emotional Labor. Journal of Occupational Health Psychology, 5, 95-110. https://doi.org/10.1037/1076-8998.5.1.95

Grandey, A. A., \& Melloy, R. C. (2017). The State of the Heart: Emotional Labor as Emotion Regulation Reviewed and Revised. Journal of Occupational Health Psychology, 22, 407-422. https://doi.org/10.1037/ocp0000067

Gross, J. J. (1998). The Emerging Field of Emotion Regulation: An Integrative Review. Review of General Psychology, 2, 271-299. https://doi.org/10.1037/1089-2680.2.3.271

Groth, M., Hennig-Thurau, T., \& Walsh, G. (2009). Customer Reactions to Emotional Labor: The Roles of Employee Acting Strategies and Customer Detection Accuracy. Academy of Management Journal, 52, 958-974. https://doi.org/10.5465/amj.2009.44634116

Guiso, L., Sapienza, P., \& Zingales, L. (2004). The Role of Social Capital in Financial Development. The American Economic Review, 94, 526-556. https://doi.org/10.1257/0002828041464498

Guiso, L., Sapienza, P., \& Zingales, L. (2008). Trusting the Stock Market. The Journal of Finance, 63, 2557-2600. https://doi.org/10.1111/j.1540-6261.2008.01408.x

Hallowell, R. (1996). The Relationship of Customer Satisfaction, Customer Loyalty and Profitability: An Empirical Study. International Journal of Service Industry Management, 7, 27-42. https://doi.org/10.1108/09564239610129931

Hansen, T. (2012). Understanding Trust in Financial Services: The Influence of Financial Healthiness, Knowledge, and Satisfaction. Journal of Service Research, 15, 280-295. https://doi.org/10.1177/1094670512439105

Hartline, M. D., Woolridge, B. R., \& Jones, K. C. (2003). Guest Perceptions of Hotel Quality: Determining Which Employee Groups Count Most. The Cornell Hotel and Restaurant Administration Quarterly, 44, 43-52. https://doi.org/10.1016/S0010-8804(03)90045-0

Hayes, A. F. (2018). An Introduction to Mediation, Moderation, and Conditional Process Analysis: A Regression-Based Approach (2nd ed.). New York: Guilford Press.

Hayes, B. E. (2008). The True Test of Loyalty. Quality Progress, 41, 20-26. 
Hochschild, A. R. (1983). The Managed Heart: Commercialization of Human Feeling. Berkeley, CA: University of California Press.

Hou, J. T., Wen, Z. L., \& Cheng, Z. J. (2004). Structural Equation Model and Its Application. Beijing: Education Science Press.

Jacoby, J., \& Chesnut, R. W. (1978). Brand Loyalty Measurement and Management. Journal of Marketing Research, 15, 121-149. https://doi.org/10.2307/3150644

Johnson, D., \& Grayson, K. (2005). Cognitive and Effective Trust in Service Relationship. Journal of Business Research, 58, 500-507. https://doi.org/10.1016/S0148-2963(03)00140-1

Kimes, M. (2010). Why Bond Funds Are Suddenly Hot. CNN.com. http://archive.fortune.com/2010/04/11/news/economy/bond_funds.fortune/index.htm

Kinnel, R. (2010). Bad Timing Eats Away at Investor Returns. Morningstar Fund Spy, February 15. http://news.morningstar.com/articlenet/article.aspx?id=325664

Komiak, S. Y. X., \& Benbasat, I. (2006). The Effects of Personalization and Familiarity on Trust and Adoption of Recommendation Agents. MIS Quarterly, 30, 941-960. https://doi.org/10.2307/25148760

Kumar, V., Pozza, I. D., \& Ganesh, J. (2013). Revisiting the Satisfaction-Loyalty Relationship: Empirical Generalizations and Directions for Future Research. Journal of Retailing, 89, 246-262. https://doi.org/10.1016/j.jretai.2013.02.001

Kuss, D. J., Griffiths, M. D., Karila, L., \& Billieux, J. (2014). Internet Addiction: A Systematic Review of Epidemiological Research for the Last Decade. Current Pharmaceutical Design, 20, 4026-4052. https://doi.org/10.2174/13816128113199990617

Lam, S. Y., Shankar, V., Erramilli, M. K., \& Murthy, B. (2004). Customer Value, Satisfaction, Loyalty, and Switching Costs: An Illustration from a Business-to-Business Service Context. Journal of the Academy of Marketing Science, 32, 293-311. https://doi.org/10.1177/0092070304263330

Larivière, B., Bowen, D., Andreassen, T. W. et al. (2017). "Service Encounter 2.0": An Investigation into the Roles of Technology, Employees and Customers. Journal of Business Research, 79, 238-246. https://doi.org/10.1016/j.jbusres.2017.03.008

Lee, H. (2017). Personality Determinants of Need for Interaction with a Retail Employee and Its Impact on Self-Service Technology (SST) Usage Intentions. Journal of Research in Interactive Marketing, 11, 214-231. https://doi.org/10.1108/JRIM-04-2016-0036

Leenheer et al. (2007). Do Loyalty Programs Really Enhance Behavioral Loyalty? An Empirical Analysis Accounting for Self-Selecting Members. International Journal of Research in Marketing, 24, 31-47. https://doi.org/10.1016/j.ijresmar.2006.10.005

Lu, J., Lu, Y., \& Lou, Y. C. (2006). Service Loyalty and Its Driving Factors: An Empirical Study Based on the Banking Industry. Management World, 8, 94-103.

Lucia-Palacios, L., Pérez-López, R., \& Polo-Redondo, Y. (2020). How Situational Circumstances Modify the Effects of Frontline Employees' Competences on Customer Satisfaction with the Store. Journal of Retailing and Consumer Services, 52, Article ID: 101905. https://doi.org/10.1016/j.jretconser.2019.101905

Massey, G. R., \& Dawes, P. L. (2007). Personal Characteristics, Trust, Conflict, and Effectiveness in Marketing/Sales Working Relationships. European Journal of Marketing, 41, 1117-1145. https://doi.org/10.1108/03090560710773372

Massey, G. R., \& Kyriazis, E. (2007). Interpersonal Trust between Marketing and R\&D during New Product Development Projects. European Journal of Marketing, 41, 1146-1172. https://doi.org/10.1108/03090560710773381

Mayer, C. (2008). Trust in Financial Markets. European Financial Management, 14, 617-632. 
https://doi.org/10.1111/j.1468-036X.2008.00454.x

McAllister, D. J. (1995). Affect- and Cognition-Based Trust as Foundations for Interpersonal Cooperation in Organizations. Academy of Management Journal, 38, 24-59. https://doi.org/10.2307/256727

Mehrabian, A., \& Russell, J. A. (1974). An Approach to Environmental Psychology. Cambridge, MA: The MIT Press.

Mittal, M., Agrawal, S., \& Gupta, R. (2019). Gender Difference in Customer Satisfaction and Brand Loyalty towards Banking Services. The IUP Journal of Marketing Management, 18, 23-38.

Nguyen, N. (2016). Reinforcing Customer Loyalty through Service Employees' Competence and Benevolence. The Service Industries Journal, 36, 13-14+721-738. https://doi.org/10.1080/02642069.2016.1272595

Nguyen, N., \& Leclerc, A. (2011). The Effect of Service Employees' Competence on Financial Institutions' Image: Benevolence as a Moderator Variable. Journal of Services Marketing, 25, 349-360. https://doi.org/10.1108/08876041111149702

Ozdemir, S., Zhang, S. J., Gupta, S., \& Bebek, G. (2020). The Effects of Trust and Peer Influence on Corporate Brand-Consumer Relationships and Consumer Loyalty. Journal of Business Research. (In Press) https://doi.org/10.1016/j.jbusres.2020.02.027

Pallant, J. (2007). SPSS Survival Manual (3rd ed.). London: McGraw-Hill.

Podsakoff, P. M., Mackenzie, S. B., \& Podsakoff, N. P. (2012). Sources of Method Bias in Social Science Research and Recommendations on How to Control It. Annual Review of Psychology, 63, 539-569. https://doi.org/10.1146/annurev-psych-120710-100452

Podsakoff, P. M., MacKenzie, S. B., Lee, J.-Y., \& Podsakoff, N. P. (2003). Common Method Biases in Behavioral Research: A Critical Review of the Literature and Recommended Remedies. Journal of Applied Psychology, 88, 879-903.

https://doi.org/10.1037/0021-9010.88.5.879

Rigdon, E. (2005). SEM FAQ. http://www.gsu.edu/ mkteer/sem.html

Riquelme, I. P., Román, S., \& Iacobucci, D. (2016). Consumers' Perceptions of Online and Offline Retailer Deception: A Moderated Mediation Analysis. Journal of Interactive Marketing, 35, 16-26. https://doi.org/10.1016/j.intmar.2016.01.002

Seger-Guttmann, T., \& Medler-Liraz, H. (2016). Does Emotional Labor Moderate Customer Participation and Buying? The Service Industries Journal, 36, 7-8+356-373. https://doi.org/10.1080/02642069.2016.1219724

Sharpe, D. L. et al. (2007). Specific Elements of Communication That Affect Trust and Commitment in the Financial Planning Process. Journal of Financial Counseling and Planning, 18, 1-17.

Sirdeshmukh, D. et al. (2002). Consumer Trust, Value, and Loyalty in Relational Exchanges. Journal of Marketing, 66, 15-37. https://doi.org/10.1509/jmkg.66.1.15.18449

Solomon, M. R., Surprenant, C., Czepiel, J. A., \& Gutman, E. G. (1985). A Role Theory Perspective on Dyadic Interactions: The Service Encounter. Journal of Marketing, 49, 99-111. https://doi.org/10.1177/002224298504900110

Srivastava, N., Dash, S. B., \& Mookerjee, A. (2015). Antecedents and Moderators of Brand Trust in the Context of Baby Care Toiletries. Journal of Consumer Marketing, 32, 328-340. https://doi.org/10.1108/JCM-09-2014-1157

Tran, G. A., \& Strutton, D. (2020). Comparing Email and SNS Users: Investigating E-Servicescape, Customer Reviews, Trust, Loyalty and E-WOM. Journal of Retailing and Consumer Services, 53, 1-17. https://doi.org/10.1016/j.jretconser.2019.03.009

Van Kleef, G. A. (2016). The Interpersonal Dynamics of Emotion: Toward an Integrative 
Theory of Emotions as Social Information. Cambridge: Cambridge University Press. https://doi.org/10.1017/CBO9781107261396

Van Kleef, G. A., Homan, A. C., \& Cheshin, A. (2012). Emotional Influence at Work: Take It EASI. Organizational Psychology Review, 2, 311-339. https://doi.org/10.1177/2041386612454911

Wang, W., Qiu, L., Kim, D., \& Benbasat, I. (2016). Effects of Rational and Social Appeals of Online Recommendation Agents on Cognition- and Affect-Based Trust. Decision Support Systems, 86, 48-60. https://doi.org/10.1016/j.dss.2016.03.007

Winchester, D., \& Huston, S. (2017). Trust Reduces Costs Associated with Consumer-Financial Planner Relationship. Journal of Financial Service Professionals, 71, 80-91.

Xie, Y., \& Peng, S. (2009). How to Repair Customer Trust after Negative Publicity: The Roles of Competence, Integrity, Benevolence and Forgiveness. Psychology and Marketing, 26, 572-589. https://doi.org/10.1002/mar.20289

Zapf, D. (2002). Emotion Work and Psychological Well-Being: A Review of the Literature and Some Conceptual Considerations. Human Resource Management Review, 12, 237-268. https://doi.org/10.1016/S1053-4822(02)00048-7

Zeithaml, V. A., Berry, L. L., \& Parasuraman, A. (1996). The Behavioral Consequences of Service Quality. Journal of Marketing, 60, 31-46. https://doi.org/10.2307/1251929

Zhang, S. (2015). An Empirical Assessment of the Impact of Brand Trust Violations in the Chinese Dairy Industry on Consumers' Repurchasing Intentions: A Brand/Consumer Relationship Perspective. Journal of Entrepreneurship in Emerging Economies, 7.

https://doi.org/10.1108/JEEE-08-2014-0030 


\section{Appendix}

\begin{tabular}{ll}
\hline \multicolumn{1}{c}{ Construct and reference } & \multicolumn{1}{c}{ Description } \\
\hline Competence & The employees give me judicious advice. \\
(five items; Nguyen, 2016) & The employees have expertise in general. \\
& The employees are easy to get appointments. \\
& They are rapid in solving the problems raised by customers durin \\
the financial service encounter. & \\
& They are confidential in solving the problems. \\
& I would feel a sense of personal loss if I could no longer use the \\
& organization. \\
Trust & I feel the organization would respond caringly to my problems in \\
general. & The organization displays a warm or caring attitude towards me. \\
(ten items; Johnson \& Grayson & I can complain freely to the organization about my problems \\
regarding their products and know that my complaint will be \\
attended to.
\end{tabular}

McAllister, 1995; Wang et al., 2016)

The organization is only interested in selling me products ${ }^{\mathrm{R}}$.

Based on the organization's past record, I have no reservations about acting on its advice.

Based on the organization's past record, I have good reason to doubt its competence ${ }^{\mathrm{R}}$.

I can rely on the organization to undertake a thorough analysis of investment products.

I have to be cautious about acting on the advice of the organization because its advice might be questionable ${ }^{\mathrm{R}}$.

I cannot confidently depend on the organization since they may be careless in the investment products ${ }^{\mathrm{R}}$.

Surface acting

The employee just pretends to have the emotions customers needed to display.

(three items; Groth et al., 2009) The employee fakes a good mood.

The employee puts on a "show" or "performance".

The employee tries to actually experience the emotions they must show to tourists.

Deep acting The employee makes an effort to actually feel the emotions that (three items; Brotheridge \& Lee, 2003)

they need to display towards tourists.

The employee works hard to feel the emotions that they need to show to tourists.

I consider this organization my first choice for the investment

Customer loyalty service.

(six items; Zeithaml et al., 1996; I am willing to continue to do business with the organization.

Nguyen, 2016)

I am happy to recommend the organization to friends and rela-
tives.
I encourage my friends and relatives to do business with the
organization.
It's my pleasure to do business with the organization.
The organization is favorable for me.

R: reversed score. 